Electronic scientific and practical journal INTELLECTUALIZATION OF LOGISTICS AND SUPPLY CHAIN MANAGEMENT

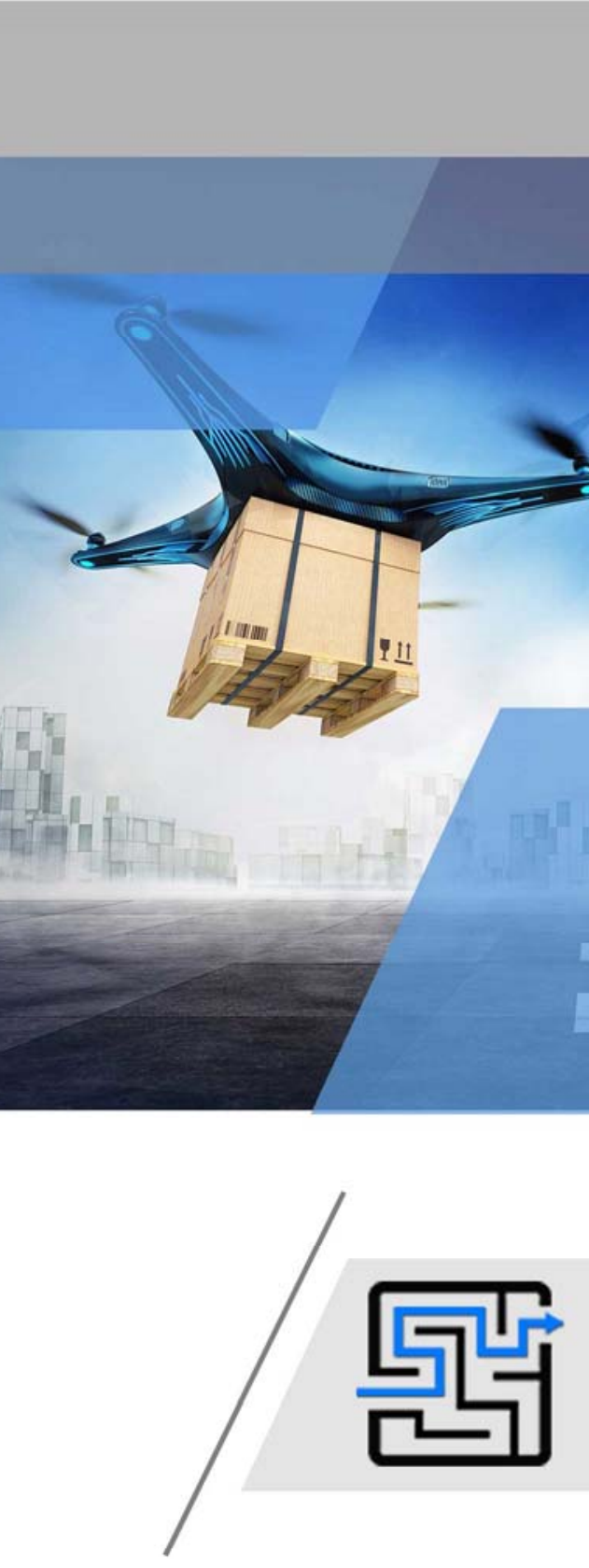

WWW.SMART-SCM.ORG

ISSN 2708-3195

DOI.ORG/10.46783/SMART-SCM/2021-7(8) 


\section{Electronic scientific and practical collection
INTELLECTUALIZATION OF LOGISTICS
AND SUPPLY CHAIN MANAGEMENT}

Electronic scientific and practical publication in economic sciences

ISSN 2708-3195

DOl: https://doi.org/10.46783/smart-scm/2021-7(8)

Released 6 times a year

№ $7(8)$ (2021)

August 2021

Kyiv - 2021 
Founder: Viold Limited Liability Company

Editor in Chief:

Deputy editors-in-chief:

Technical editor:

Executive Secretary:
Hryhorak M. Yu. - Doctor of Economics, Ass. Professor.

Koulyk V. A. - PhD (Economics), Professor.

Marchuk V. Ye. - Doctor of Tech. Sci., Ass. Professor.

Harmash O. M. - PhD (Economics), Ass. Professor.

Davidenko V. V. - PhD (Economics), Ass. Professor.

\section{Members of the Editorial Board:}

SWIEKATOWSKI Ryszard - Doctor of Economics, Professor (Poland);

POSTAN M. Ya. - Doctor of Economics, Professor;

TRUSHKINA N. V. - PhD (Economics), Corresponding Member of the Academy;

KOLOSOK V. M. - Doctor of Economics, Professor;

ILCHENKO N. B. - Doctor of Economics, Ass. Professor;

SOLOMON D. I. - Doctor of Economics, Professor (Moldova);

ALKEMA V. H. - Doctor of Economics, Professor;

Henryk DŹWIGOŁ - PhD (Economics), Professor (Poland);

SUMETS O. M. - Doctor of Economics, Ass. Professor;

STRELCOVÁ Stanislava - PhD (Economics), Ass. Professor, (Slovakia);

RISTVEJ Jozef (Mr.) PhD (Economics), Professor, (Slovakia);

ZAMIAR Zenon - Doctor of Economics, Professor, (Poland);

SMERICHEVSKA S. V. - Doctor of Economics, Professor;

GRITSENKO S. I. - Doctor of Economics, Professor;

KARPENKO O. O. - Doctor of Economics, Professor;

PATKOVSKYI S. A. - Business practitioner.

The electronic scientific and practical journal is registered in international scientometric data bases, repositories and search engines. The main characteristic of the edition is the index of scientometric data bases, which reflects the importance and effectiveness of scientific publications using indicators such as quotation index, $\mathrm{h}$-index and factor impact (the number of quotations within two years after publishing).

In 2020, the International Center for Periodicals (ISSN International Center, Paris) included the Electronic Scientific and Practical Edition "Intellectualization of Supply Chain Management" in the international register of periodicals and provided it with a numerical code of international identification: ISSN 2708-3195 (Online).

Recommended for dissemination on the Internet by the Academic Council of the Department of Logistics NAU (No. 7 of February 26, 2020). Released 6 times a year. Editions references are required. The view of the editorial board does not always coincide with that of the authors.

t.me/smart_scm facebook.com/Smart.SCM.org twitter.com/ScmSmart

DOI: https://doi.org/10.46783/smart-scm/2021-7(8) e-mail: support@smart-scm.org тел.: (063) 593-30-41

https://smart-scm.org 


\section{Contents}

INTRODUCTION

HRYHORAK M.Yu. Doctor of Science in Economics, Associate Professor, Head of Logistics Department of National Aviation University (Ukraine), DZWIGOL Henryk. PhD DSc, Associate professor, Professor - Organization and Management Silesian University of Technology in Gliwice (Poland), KWILINSKI Aleksy Ph.D., Doctor of Economics, Professor, The London Academy of Science and Business (London, United Kingdom), TRUSHKINA N.V. PhD (Economics), Associate Professor, Senior Research Fellow, Regulatory Policy and Entrepreneurship Development Institute of Industrial Economics of the National Academy of Sciences of Ukraine (Ukraine), OVDIIENKO O.V., PhD student, Assistant of Logistics Department of National Aviation University (Ukraine)

ON THE APPLICATION OF THE CONCEPT OF CIRCULAR ECONOMY TO ENSURE BALANCED SUSTAINABLE DEVELOPMENT OF THE NATIONAL LOGISTICS SYSTEM IN UKRAINE

VOLOVYK O.I. Senior Lecturer of Logistics Department, National Aviation University (Ukraine), TSAPENKO O.A. Student of Logistics Department of National Aviation University (Ukraine)

ANALYSIS OF PROFESSIONAL REQUIREMENTS FOR A MODERN LOGISTICIAN

MARCHUK V.Ye Doctor of Engineering, Associate Professor, Professor of Logistics Department National Aviation University (Ukraine), SAVCHENKO L.V. PhD of Technical Sciences, Associate Professor, Associate Professor of Logistics Department of National Aviation University (Ukraine), HARMASH O.M., PhD of Economics, Associate Professor, Associate Professor of Logistics Department of National Aviation University (Ukraine)

MANAGEMENT OF REVERSE LOGISTICS IN THE SUPPLY CHAIN SYSTEM

KULIK V.A., PhD (Economics), Professor, Professor of Logistics Department National Aviation University, Honored Worker of National Education of Ukraine, Honorary employee of aviation transport of Ukraine (Ukraine), SEMERIAHINA M. M., Senior Lecturer of Logistics Department, National Aviation University (Ukraine), RISTVEJ Jozef PhD (Economics), Professor, Vice-Rector University of Zilina (Slovakia), ZAHARCHUK A.P. Assistant of the Logistics Department of National Aviation University (Ukraine)

POLYCENTRIC MANAGEMENT OF THE GLOBAL SUPPLY CHAIN INTEGRATION

DAVYDENKO V.V., PhD of Economics, Associate Professor, Associate Professor of Logistics Department of National Aviation University (Ukraine), KARPUN O.V. PhD in Economics, Associate Professor, Associate Professor of Logistics Department National Aviation University (Ukraine), ZAMIAR Zenon Dr. hab. Inż, Professor, ViceRector the International University of Logistics and Transport in Wroclaw (Poland), KOSTIUCHENKO L.V. PhD in Economics, Associate Professor, Associate Professor of Department of National Aviation University (Ukraine) STRATEGIC MANAGEMENT OF THE ENTERPRISE IN THE CONDITIONS IN THE INSTABILITY OF THE MARKETENVIRONMENT 
UDC 005.932:331.54

DOI: https://doi.org/10.46783/smart-scm/2021-7(8)-2

JEL Classification: C42, J23, J63, M12, 015.

Received: 12 June 2021

Volovyk O.I. Senior Lecturer of Logistics Department, National Aviation University (Ukraine)

ORCID - 0000-0001-7718-8732

Researcher ID -

Scopus author id: -

Tsapenko O.A. Student of Logistics Department of National Aviation University (Ukraine)

ORCID -

Researcher ID -

Scopus author id: -

\title{
ANALYSIS OF PROFESSIONAL REQUIREMENTS FOR A MODERN LOGISTICIAN
}

\begin{abstract}
Olena Volovyk, Oleksandr Tsapenko "Analysis of professional requirements for a modern logistician". The article is devoted to the research of modern labour market requirements for experts in logistics. The reasons of logistics importance for the proper functioning of national and international economies were outlined. The list of requirements set by business representatives to successful candidates is summarized. The analysis of the job market was performed using topic-related websites that cover job markets in Ukraine, the United Kingdom of Great Britain, Austria, Slovakia and the Russian Federation. Empirical studies, data analysis and synthesis, expert assessments, and generalization methods were used to perform the scientific inquiry. The number of specific competencies mentions in the job ads analyses and the relative difference between studies' indicators were counted. It was revealed that there is a great demand in almost all areas of the economy for logistics specialists. The tendency to find the personnel, who are willing to learn and improve on a continual basis, and can demonstrate a larger range of soft skills in addition to being an effective communicator, has been traced. Assumptions were made about possible changes in the requirements of employers to candidates, in connection with the presence of drivers of Industry 4.0 environment forming. Recommendations for further research of labour market requirements were provided.
\end{abstract}

Keywords: logisticians, competences, hard skills, soft skills, labour market of logistics, logistic, statistics.

Олена Воловик, Олександр Цапенко. "Аналіз професійних вимог до сучасного логіста". Стаття присвячена дослідженню сучасних вимог ринку праці до фахівців з логістики. Окреслено значення логістики для належного функціонування національної та міжнародної економік. Узагальнено перелік вимог, які висувають представники бізнесу до кандидатів. Аналіз ринку праці було проведено за допомогою тематичних веб-сайтів, які охоплюють ринки праці в Україні, Великій Британії, Австрії, Словаччині та Російській Федерачії. Для проведення дослідження були використані емпіричні дослідження, аналіз та синтез даних, експертні оцінки та методи узагальнення. Підраховано кількість згадок конкретних компетенцій, про які йдеться в аналізованих оголошеннях про роботу, та відносну різницю між показниками досліджень. Було виявлено, що практично у всіх сферах економіки існує великий попит на фахівців з логістики. Виявлено тенденцію до пошуку 
персоналу, який готовий постійно вчитися та вдосконалюватися, та, окрім навичок ефективного спілкування, може продемонструвати більший діапазон "м'яких навичок". Були зроблені припущення щодо можливих змін у вимогах роботодавців до кандидатів у зв'язку з наявністю драйверів формування середовища Індустрії 4.0. Надано рекомендації щодо подальшого дослідження вимог ринку праці.

Ключові слова: логісти, компетентності, «жорсткі навички», «м'які навички», ринок праці з логістики, логістика, статистика.

Елена Воловик, Александр Цапенко. "Анализ профессиональных требований к современному логисту". Статья посвящена исследованию современных требований рынка труда к специалистам по логистике. Определена значимость логистики для надлежащего функционирования национальной и международной экономик. Обобщен перечень требований, которые выдвигают представители бизнеса к кандидатам. Анализ рынка труда был проведен с помощью тематических сайтов, которые охватывают рынки труда в Украине, Великобритании, Австрии, Словакии и Российской Федерачии. Для проведения исследования были использованы эмпирические исследования, анализ и синтез данных, экспертные оценки и методы обобщения. Подсчитано количество упоминаний конкретных компетенций, о которых говорится в анализированных объявлениях о работе, и относительную разницу между показателями исследований. Было обнаружено, что практически во всех срерах экономики существует большой спрос на специалистов по логистике. Выявлена тенденция к поиску персонала, который готов постоянно учиться и совершенствоваться, и, кроме навыков эффективного общения, может продемонстрировать больший диапазон "мягких навыков". Были сделаны предположения относительно возможных изменений в требованиях работодателей к кандидатам в связи с наличием драйверов формирования среды Индустрии 4.0. Даны рекомендачии по дальнейшему исследованию требований рынка труда.

Ключевые слова: логисты, компетенции, «жесткие навыки», «мягкие навыки», рынок труда логистики, логистика, статистика.

Introduction. Nowadays, a career in logistics is one of the most popular areas of option for university admission and employment in Ukraine and is considered to be among the ten most popular professions in the near future, according to the Rail.insider review (2021) [1]. It can be said that a logistician operates as an organizer of any process in different areas of the company's activity. Since logistics has gone beyond the frames of being a technical speciality towards a managerial position, these specialists have become widespread in different spheres of economic activities like production, retail, transportation, etc. Moreover, this profession is regarded as one of the fundamental areas of activity of an organization which involves such operational activities as product distribution and transportation.

The current research justifies the high demand for logisticians with a steady tendency for growth, and outlines the requirements for competencies of the labour market. This study can help junior job seekers assess the level of demand from employers, as well as provide higher education institutions with ideas on how to meet the requirements of the ever-changing business and economic environment in order to achieve a competitive advantage.

Analysis of the latest research. The issues of the labour market in logistics and the requirements of employers for logistic professionals have been explored by such scientists as D. Bowersox, D. Closs, M. Bixby Cooper, A. Harrison, R. van Hoek, M. Grygorak, E. Krykavsky, O. Pokhylchenko, and others [2$5,10]$. The majority of prior research has emphasized the main task of the logistician as to optimize the material flows management, because their high level of expertise directly leads to the costs reduction, which, in turn, increases the profitability of the business. The list of competences for a logistician which meets the requirements of the contemporary labour market can be formed based on the 
analysis of the potential responsibilities which will involve careful preparation and maintenance of inventory records, demand structure, contractors selection, human resource management, and so on [6]. According to D. Bugayko, A. Vasylenko and D. Grabovsky (2018), logistics professionals are among the most needed and prestigious employees, because almost all business processes contain a logistics component [7].

Currently, the share in the labour market for logisticians is still growing based on the data provided by Yu. Bratyshko, O. Posylkina, and G. Kubasova (2018). In particular, the share of vacancies for the positions of "Logistician" and "Logistics Manager" on job search sites accommodates up to $1.5 \%$ of the total number of job ads. This trend is due to the national dynamics of the Ukrainian economy as a whole and the labour market of Ukraine in particular which leads to positive dynamics of wages, increased number of registered vacancies, predominance of the hired staff number over the retired, and so on [8].

M. Shevchun (2020) states that companies experience a shortage of proficient logistic managers. They are forced to "steal" employees from each other through attracting successful candidates by growing monetary compensations. Businesses try to hire an employee who possess soft skills in addition to technological ones as well which include though not limited to knowledge of specialized software, types of loaders and equipment, etc. [9]. Another steady trend which has become peculiar to Industry 4.0 for the past decade is a strong growing demand for IT competences among candidates. $O$. Pokhylchenko (2019) suggested that "without digital technology supply chains have no future. That is why the requirement for top managers is to focus on building teams in order to identify the best ways to harness the powerful potential of digital technologies in their supply chains" [10].

Formulation of the purpose of the study. The purpose of this article is to explore the job ads for professions related to logistics, organise the data in a meaningful manner and analyse the obtained results in order to identify the modern labour market requirements for experts in logistics and related areas. This paper also aims to formulate assumptions about the required future skills for a logistics manager in the Industry 4.0 environment as a key driver of forming a new generation of professionals. To ensure the realization of these goals, the following research methods were used in scientific inquiry: empirical studies, data analysis and synthesis, expert assessments, and generalization.

The main research. Prior to the start of research on labour market offers, it is necessary to describe the reasons why logistics is important for the proper functioning of national and international economies, and factors of popularity among potential specialists in this sphere.

According to the Council of Supply Chain Management Professionals (2005), logistics is "planning, managing, and implementing an effective, powerful flow and storage of goods and related information from point of origin to point of consumption, which aims to satisfy customer requirements" [11]. These actions form the idea of integrating many activities toward supporting a certain objective, which comes from a particular task needed to be solved by a decision maker.

In the field of logistics or transport, the nature of the work of professionals is specific. Managers in this branch of economy must acquire such competencies as basics of business organization and information management, order processing, warehousing, process management, etc. Referring to I. Smirnov and T. Kosareva (2008), logisticians are expected to promote business development in general, create and administrate transport companies or departments, organize activities, prepare and arrange documentation necessary for the development of business relations, initiate and implement innovations, giving priority to international transport and logistics activities, in order to improve the business 
performance. That is why, the contribution of well-trained professionals to the growth and prosperity of the economy has a very large impact [12]. The modern trend in logistics specifies a variety and diversity of its type, such as: transports, distribution, purchase, finance, personnel, reverse, service, strategic and other branches of logistics. Though, the research showed that general requirements for a professional are approximately the same with disregard of the implementation area. The list of them, formulated by the employers, is the following:

- Higher education (preferably a master's degree);

- Knowledge of foreign languages;

- IT and specific software skills;

- Communication skills;

- Analytical thinking and system thinking;

- Leadership and creativity;

- Diligence, reliability, punctuality;

- Presentation skill including effective self-presentation.

The outline of the specifics and basic professional requirements in a sphere of logistics management eloquently identifies the features of logistics application in different fields of professional and scientific activity. To investigate further the list of qualifications needed, the analysis of available job advertisement sources, systematization, and summarization of the information collected, as well as graphic modelling used to build the diagrams and competence radar, were completed.

The first stage of the research was carried out in the mid-November 2020. This period was characterized by an introduction of stricter measures in quarantine restrictions due to the unfolding of a new wave of the pandemic and the absence of vaccination processes. Meanwhile, there was an increased level of applicants (for example, university graduates), as well as the creation of new job places with the prospect for the next economic year and to fill in the new one, connected with projects to support the recovery of state economy during the afterpandemic crisis. From the total mass of vacancies, a selection of 30 random ads for each trial was perfumed: 13 - from Ukrainian sources (such as rabota.ua, work.ua, and grc.ua), 5 - from British (reed.co.uk) and by 4 from Austrian, Slovak, and Russian (karriere.at, profesia.sk, hh.ru). The same websites were used during both stages of research. There were attempts to analyse the situation with job market in Poland and Germany, as those countries have sufficient representation of Ukrainians on their job markets. But the access to German recruiting websites is banned outside the country. Polish sources did not provide proposals on wages or a full list of requirements. Interested readers can get acquainted with the full array of data sample via contacting the authors.

During the task implementation, the following search queries and their equivalents in languages used on the site were applied: logistician; logistics manager (manager of logistics); specialist in logistics; transportation manager/coordinator. During the analysis of the collected information, the following criteria were used to summarize it:

- Job title (position);

- Source and country;

- Industry and company;

- Proposed amount of salary;

- General competences for a candidate.

In most cases, the title of the ad reflects the name of the position - logistician or logistics manager. Almost all economic spheres show a great demand for specialists in this area, more often in transportation and delivery, production, retail. The amount of month salary is above the average level in countries, but with exceptions.

Generally, every analysed job advertisement lists about five-seven requirements. Higher education (preferably specialized), work experience in the field from one to three years and computer skills are mandatory by two-thirds of employers. Knowledge of foreign languages is required in every third job advertisement. Age and gender requirements are specified only in 
some items from one Ukrainian source: generalizing, male from 25 to 40 . Pertaining personal skills, about half of vacancies are accompanied by the requirement for proficient communication ones. Thirty-three percent of job ads indicated that there is a need for strong time management, selforganization and other types of skills from the side of the applicant. The absolute and relative frequencies of the indicated criteria are summarized in Table 1:

Table 1. The number of specific competencies mentions in the first job ads analysis

\begin{tabular}{|l|l|l|l|}
\hline № & Competence & $\begin{array}{l}\text { Frequency of } \\
\text { mentioning }\end{array}$ & $\begin{array}{l}\text { Relative } \\
\text { frequency }\end{array}$ \\
\hline 1 & Higher education & 17 & 0.57 \\
\hline 2 & Age and/or gender requirements & 3 & 0.10 \\
\hline 3 & IT skills and knowledge of special software & 21 & 0.70 \\
\hline 4 & Work experience & 21 & 0.70 \\
\hline 5 & Foreign languages knowledge & 11 & 0.37 \\
\hline 6 & Driver license & 3 & 0.10 \\
\hline 7 & Knowledge of legislations and documents & 7 & 0.23 \\
\hline 8 & Communication skills & 16 & 0.53 \\
\hline 9 & Time management and responsibility & 12 & 0.40 \\
\hline 10 & Self-organization and attentiveness & 10 & 0.33 \\
\hline 11 & Other personal skills (except 8-10) & 14 & 0.47 \\
\hline
\end{tabular}

Source: compiled by the authors

An analysis of the frequency of particular requirement was also carried out in the context of the vacancy sources and is shown on the following bar chart (Fig. 1). 


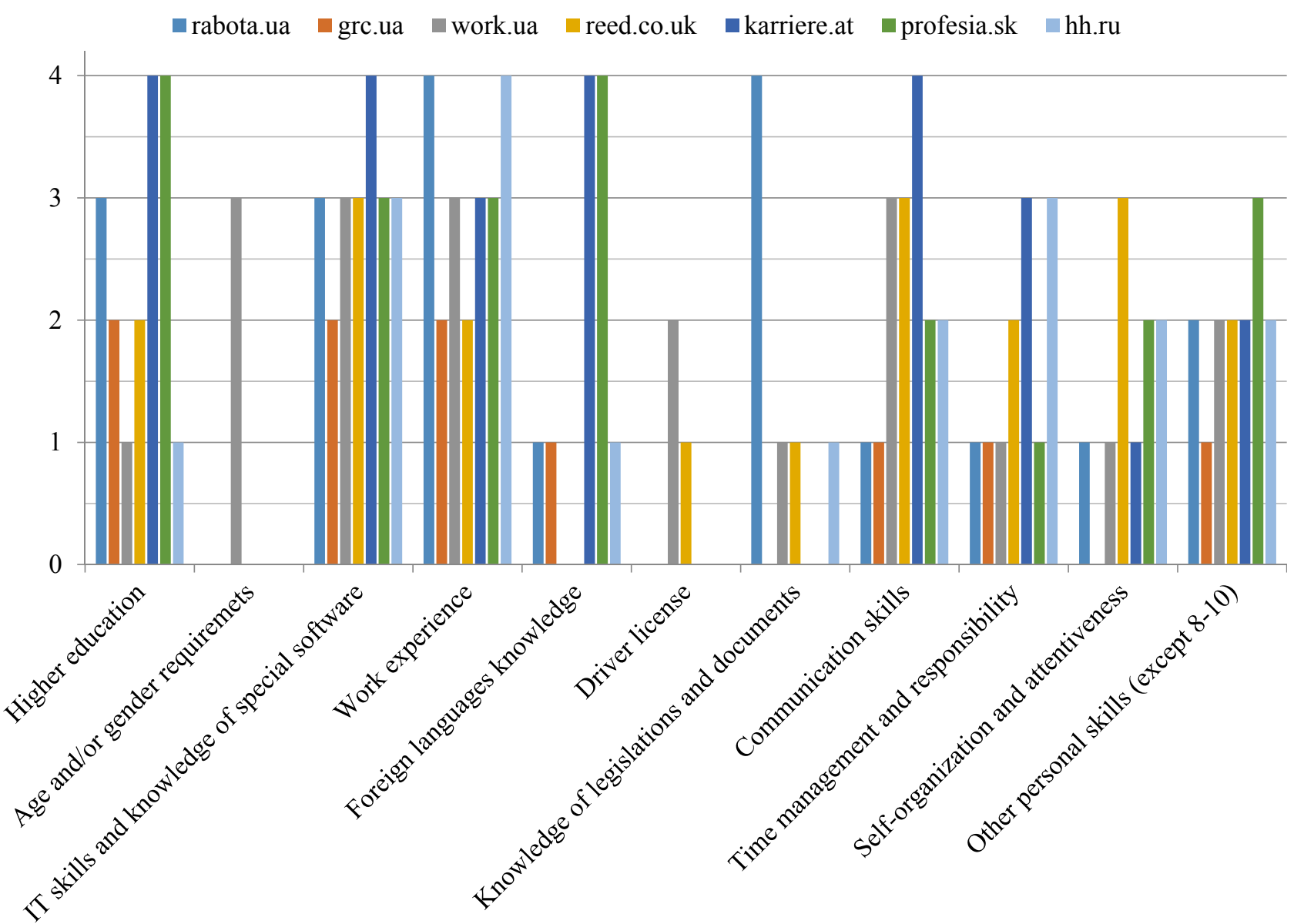

Figure 1 - The quantitative comparison of requirements for logistics manager competencies based on collected job-type ads within the sources, November 2020

Source: compiled by the authors

The data were re-collected and the second re-examination was performed in August 2021. This month was characterized by attempts to revive pre-quarantine methods of doing business, due to a decrease in the incidence of COVID-19, active vaccination procedures all around the world, and, as a result, the abolition of the imposed strict quarantine restrictions. Actually, an increase in vacancies resulted from the revival of areas affected by the lockdowns. Worth mentioning that the summer period for job search is the most demanded by university students and graduates. The second study fully used the technique and methodology of the first one that makes the results consistent and comparable.
Pertaining to the result of the second wave of observations, the average number of requirements per vacancy decreased to foursix items that can be attributed to the outflow of personnel, in particular, abroad or to other areas of economic activity. Mostly, the transportation and production spheres are seeking professionals of that kind. The demand for candidates with higher education possessing strong self-organization (from $33 \%$ to $57 \%$ ) and communication skills has risen. Comparing to the data from November 2020, the number and range of other criteria have increased, in particular, for hard skills and soft skills, which are different from those presented in the previous list for analysis. There is a tendency of demanding the personnel who are willing to learn and 
continually improve, and can demonstrate a larger range of soft skills in addition to being an effective communicator (i.e. being quick learners, stress-resistant, possess strong decision-making skills, etc.).
The table summarizing the number of occurrences for each requirement together with the corresponding relative values compares the results of both stages of the research (Table 2):

Table 2. The number of specific competencies mentions in the second job ads analysis and relative difference between studies' indicators

\begin{tabular}{|l|l|l|l|l|l|l|}
\hline \multirow{2}{*}{ № } & \multirow{2}{*}{ Kompetence } & \multicolumn{2}{|c|}{ November 2020} & \multicolumn{2}{c|}{ August 2021 } & \multirow{2}{*}{$\begin{array}{c}\text { Relative } \\
\text { difference }\end{array}$} \\
\cline { 3 - 6 } & $\begin{array}{c}\text { Frequency of } \\
\text { mentioning }\end{array}$ & $\begin{array}{c}\text { Relative } \\
\text { frequency }\end{array}$ & $\begin{array}{c}\text { Frequency of } \\
\text { mentioning }\end{array}$ & $\begin{array}{c}\text { Relative } \\
\text { frequency }\end{array}$ & \\
\hline 1 & Higher education & 17 & 0.57 & 19 & 0.63 & 0.06 \\
\hline 2 & Age and/or gender requirements & 3 & 0.10 & 2 & 0.07 & -0.03 \\
\hline 3 & $\begin{array}{l}\text { IT skills and knowledge of } \\
\text { special software }\end{array}$ & 21 & 0.70 & 23 & 0.77 & 0.07 \\
\hline 4 & Work experience & 21 & 0.70 & 22 & 0.73 & 0.03 \\
\hline 5 & Foreign languages knowledge & 11 & 0.37 & 13 & 0.43 & 0.06 \\
\hline 6 & Driver license & 3 & 0.10 & 2 & 0.07 & -0.03 \\
\hline 7 & Knowledge of legislations and documents & 7 & 0.23 & 7 & 0.23 & 0 \\
\hline 8 & Communication skills & 16 & 0.53 & 20 & 0.67 & 0.14 \\
\hline 9 & Time management and responsibility & 12 & 0.40 & 12 & 0.40 & 0 \\
\hline 10 & Self-organization and attentiveness & 10 & 0.33 & 17 & 0.57 & 0.24 \\
\hline 11 & $\begin{array}{l}\text { Other personal skills } \\
\text { (except 8-10) }\end{array}$ & 14 & 0.47 & 24 & 0.80 & 0.33 \\
\hline
\end{tabular}

Source: Compiled by the authors

Similar approaches were applied in the second stage of the study, which was carried

out in August 2021, and the corresponding results are presented in Fig. 2. 


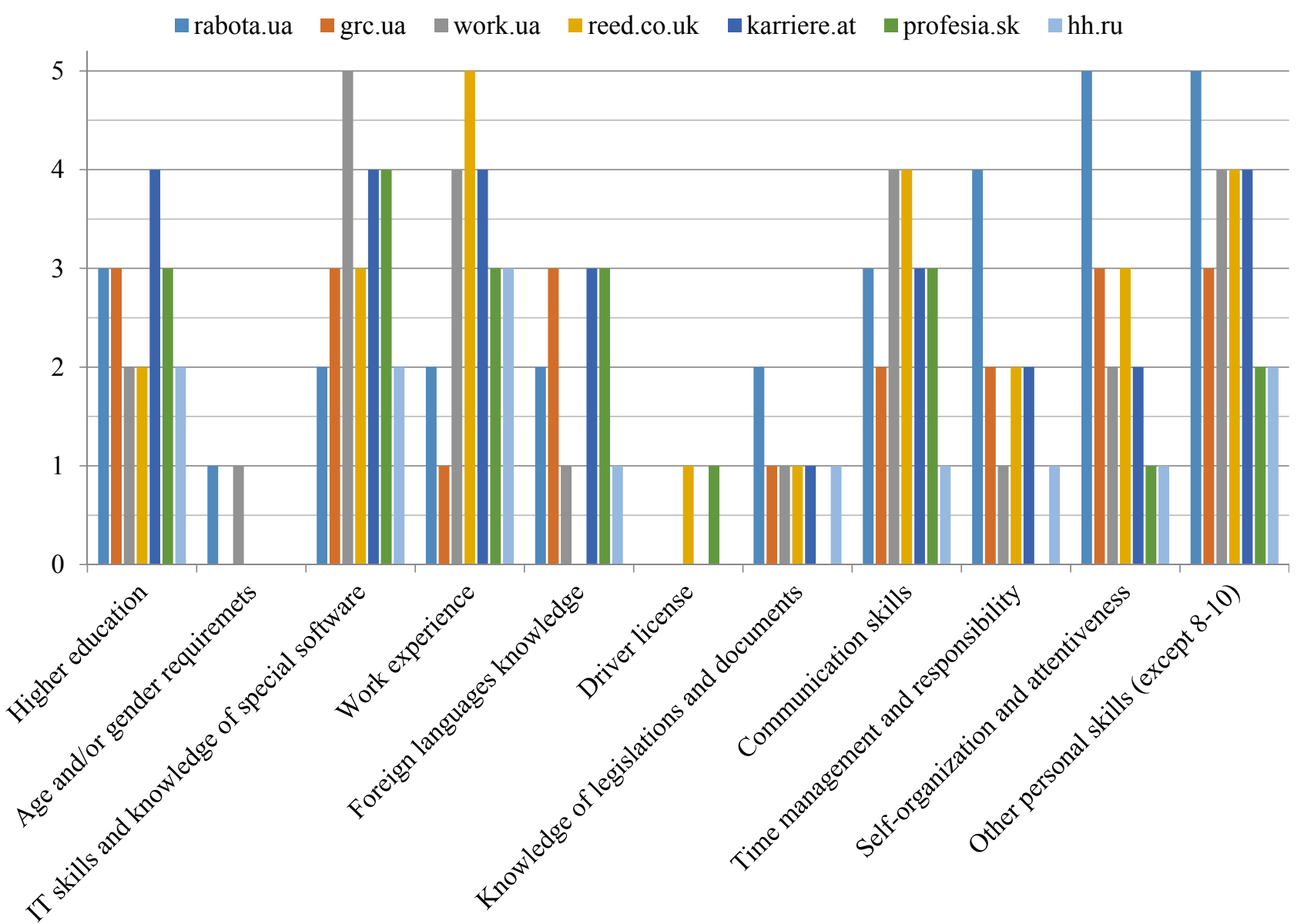

Figure 2 - The quantitative comparison of requirements for logistics manager competencies based on collected job-type ads within the sources, August 2021 Source: Compiled by the authors

The obtained results can be summarised using the competence radar, based on the same criteria listed before. They will be evaluated on a 5-point scale, marking competencies as they are mentioned in ads from the sample (Fig. 3). The authors' own assessment of the criteria application in the professionals' selection process is also added to this graph along with an explanation of each.

The authors agree with the importance of higher education and developed soft skills for the logistician of the $21 \mathrm{st}$ century. The knowledge gained at the university is a solid foundation for any expert. Languages and computer skills are considered to be musthaves, but could be learned at any age.
Proficiency in documentation flow processes is desirable, but it may be recovered with a quick search on the Internet to remain updated on ever-changing regulatory policies. Work experience indicates a level of expertise, but this requirement might neglect a lot of talented students and graduates who lack experience due to their age. In most cases, job ads that indicate work experience as a required competence offer more favourable working conditions, payment compensations and work incentives. A driver licence could be in need in case of intensive travelling. Public transport and taxis are the partial or full replacement of driving. Age or gender requirements are considered as infringing on the rights of potential applicants. 


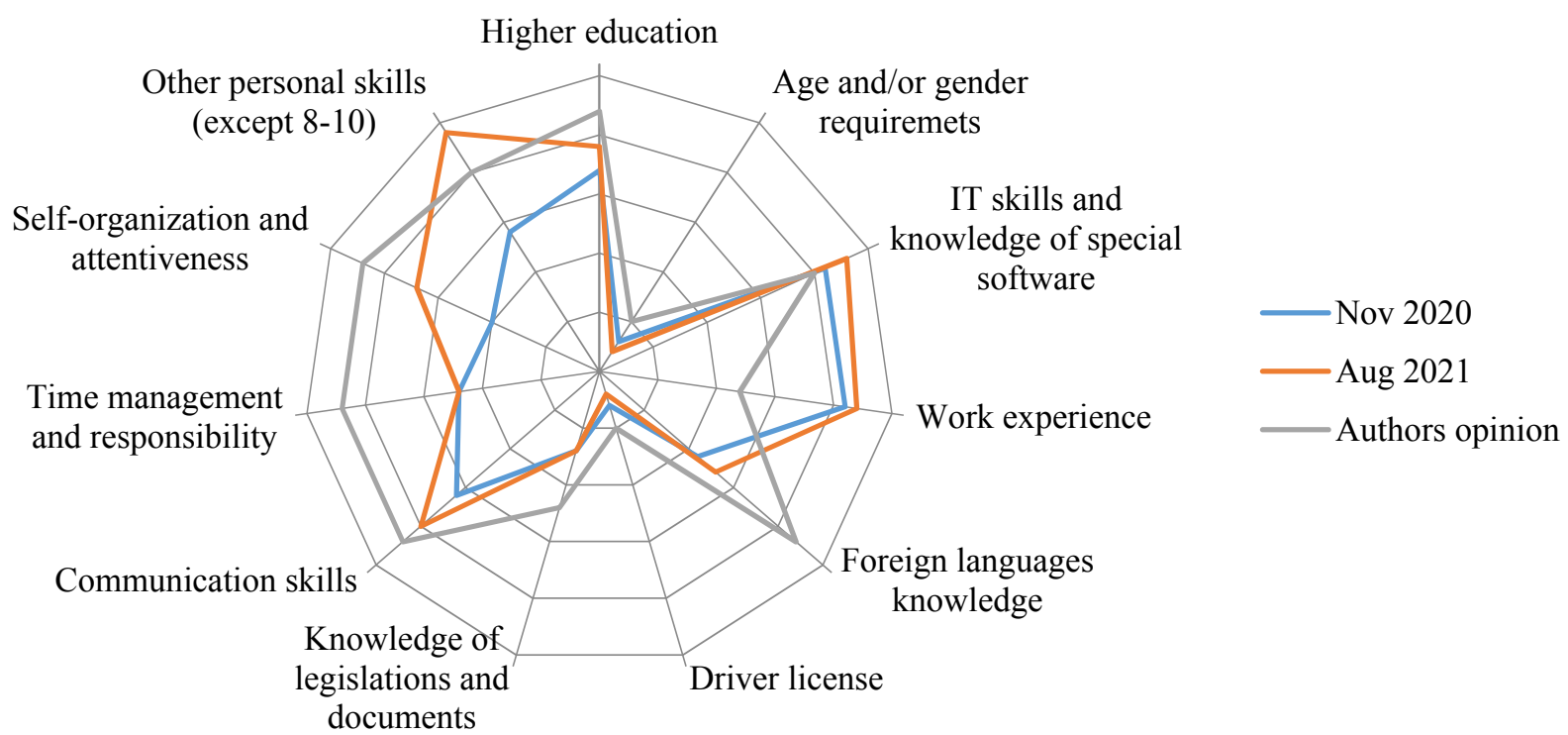

Figure 3 - The competence radar, based on the materials of research done, and authors' own view Source: compiled by the authors

Based on the research data, it can be assumed that contemporary employers prefer candidates with work experience rather than higher education in the field of supply chain management or transport technologies: the stronger work experience, the higher the starting salary.

While comparing job offers coming from domestic and foreign vacancy-related sites, it was discovered that Ukrainian employers need professionals with completed higher education and have work experience in logistics. Foreign companies prefer graduates with dual or multiple educational degrees, solid training in management, proficiency in IT, knowledge of economics and languages. Among soft skills, employers seek candidates with strong self-management, self-learning and self-improvement ones. An increase of the foreign labour markets trends impact on the Ukrainian one may be expected.

Conclusions. The logistics market continues to grow rapidly and develops a high potential for employment. The most important tasks for logistics managers at all levels are to optimize logistics costs and risk management. Logistics belongs to the number of highly paid and prestigious fields of employment. The research conducted in November 2020 and August 2021 showed that the labour market needs professionals who have completed higher education supported by strong business experience and are aware of the specifics in the field, accompanied by well-developed communication and personal skills. The list of competencies for a successful candidate for the position of a logistician needs continual revision as it represents a highly sensitive field 
of the economy that depends on changes in

the business, economic, social and technological environment.

\section{References}

1. Kopylov, M. (2021). Where logistics is taught in Ukraine. Rail.Insider. URL: https://www.railinsider.com.ua/de-v-ukrayini-navchayut-logistyczi/

2. Bowersox D., Closs D. and Bixby Cooper M. (2019). Supply Chain Logistics Management. 4th Edition. McGraw-Hill Higher Education, 678 p.

3. Harrison A., van Hoek R. (2019). Logistics Management and Strategy Competing Through the Supply Chain. 6th Edition. Prentice Hall, 317 p.

4. Grygorak, M. (2017). Intellectualization of the logistics services market: concept, methodology, competence: Monograph. Kyiv: Sic Group Ukraine, 513 p.

5. Krykavsky E., Pokhylchenko O., Fertch M. (2019). Logistics and supply chain management. Lviv: Lviv Polytechnic Publishing House, 848 p.

6. Van Duin, R. (2012). Logistics Concept Development in Multi-Actor Environments (Doctor Thesis). http://dx.doi.org/10.13140/2.1.1426.9122

7. Bugayko D., Vasylenko A., Grabovsky D. (2018). Logistics labour market analysis and requirements submitted by employers to logistics. Proceedings of the XVI International Scientific and Practical Conference "Problems of training professional personnel in logistics in a global competitive environment", Kyiv. 26-27.10.2018, p. 40-43.

8. Bratyshko, Yu., Posylkina O., Kubasova G. (2018). Research of labor market needs in logistics managers. Management, economics and quality assurance in pharmacy, № 4 (2018), p. 5058. https://doi.org/10.24959/uekj.18.33

9. Shevchun M. B. Problems and prospects of training specialists in the field of logistics in modern conditions. Problems of training professionals in logistics in a global competitive environment: Proceedings of the XVIII International scientific-practical conference. - 2020. - p. 415418

10. Pokhylchenko O. (2019). Logistics and supply chain management trends in transformation change projection of Industry 4.0. Intellect XXI, №3, p. 149-154. http://www.intellect21.nuft.org.ua/journal/2019/2019_3/26.pdf

11. Ballou R. (2006). The evolution and future of logistics and supply chain management. Produção. $\quad$ v. 16, n. 3, p. 375-386, Set./Dez. 2006. http://dx.doi.org/10.1590/S010365132006000300002

12. Smirnov I., Kosareva T. (2008). Transport logistics. Tsentr uchbovoi literatury, 220 p. 